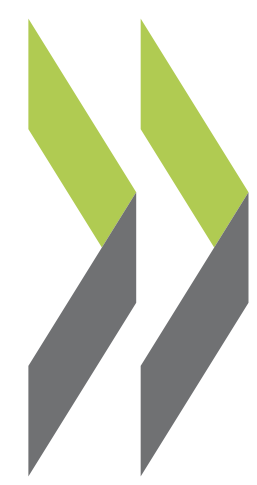

OECD Economics Department Working Papers No. 1647

Liquidity shortfalls during the COVID-19 outbreak: Assessment and policy responses

\section{Lilas Demmou,}

Guido Franco,

Sara Calligaris,

Dennis Dlugosch 
ECONOMICS DEPARTMENT

\section{LIQUIDITY SHORTFALLS DURING THE COVID-19 OUTBREAK: ASSESSMENT AND POLICY RESPONSES}

\section{ECONOMICS DEPARTMENT WORKING PAPERS No. 1647}

By Lilas Demmou, Guido Franco, Sara Calligaris and Dennis Dlugosch

OECD Working Papers should not be reported as representing the official views of the OECD or of its member countries. The opinions expressed and arguments employed are those of the author(s).

Authorised for publication by Luiz de Mello, Director, Policy Studies Branch, Economics Department.

All Economics Department Working Papers are available at www.oecd.org/eco/workingpapers.

JT03470246 
OECD Working Papers should not be reported as representing the official views of the OECD or of its member countries. The opinions expressed and arguments employed are those of the author(s).

Working Papers describe preliminary results or research in progress by the author(s) and are published to stimulate discussion on a broad range of issues on which the OECD works.

Comments on Working Papers are welcomed, and may be sent to OECD Economics Department, 2 rue André Pascal, 75775 Paris Cedex 16, France, or by e-mail to eco.contact@oecd.org.

All Economics Department Working Papers are available at www.oecd.org/eco/workingpapers.

This document and any map included herein are without prejudice to the status of or sovereignty over any territory, to the delimitation of international frontiers and boundaries and to the name of any territory, city or area.

The statistical data for Israel are supplied by and under the responsibility of the relevant Israeli authorities. The use of such data by the OECD is without prejudice to the status of the Golan Heights, East Jerusalem and Israeli settlements in the West Bank under the terms of international law.

(C) OECD (2021)

You can copy, download or print OECD content for your own use, and you can include excerpts from OECD publications, databases and multimedia products in your own documents, presentations, blogs, websites and teaching materials, provided that suitable acknowledgment of OECD as source and copyright owner is given. All requests for commercial use and translation rights should be submitted to PubRrights@oecd.org. 


\section{ABSTRACT / RESUME}

\section{Liquidity shortfalls during the Covid-19 outbreak: assessment and policy responses}

The paper investigates the financial vulnerability of non-financial firms during the Coronavirus (COVID-19) epidemic crisis. In particular, it evaluates the extent to which firms may run into a liquidity crisis following the COVID-19 outbreak and the impact of stylised policy measures to reduce the risks and depth of such crisis. The analysis relies on three ingredients: a simple accounting model, a large dataset reporting firms' balance sheets for 14 countries and granular data on the magnitude of the shock measuring the impact of confinement measures on economic activity (notably depending on the capacity of each sector to operate by teleworking). Results suggest that, without any policy intervention, up to $38 \%$ of firms would face liquidity shortfalls after 10 months since the implementation of confinement measures. Comparing the impact of different policies (tax deferral, debt moratorium and support to wage payments), the analysis shows that government support to relieve wage bills is the most effective tool to reduce liquidity shortages, followed by debt moratorium policies. Finally, the paper zooms into labour market policies and compares the costefficiency of short-term work and wage subsidies schemes, highlighting how their relative efficiency depends on their design.

JEL Classification codes: D22, D24, J38, H81.

Keywords: COVID-19, liquidity, cash, job retention.

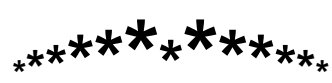

\section{Crise de liquidité pendant l'épidémie du COVID-19 : évaluation et réponses politiques}

L'article étudie la vulnérabilité financière des entreprises non financières pendant la crise épidémique du coronavirus (COVID-19). Il évalue en particulier la mesure avec laquelle les entreprises ont été confrontées à une crise de liquidité suite à l'épidémie de COVID-19 ainsi que l'impact des mesures de politiques publiques visant à réduire les risques et la profondeur d'une telle crise. L'analyse repose sur trois ingrédients: un simple modèle comptable, des données de bilans d'entreprises couvrant 14 pays et des données granulaires sur l'ampleur du choc mesurant l'impact des mesures de confinement sur l'activité économique (en fonction notamment de la capacité de chaque secteur à fonctionner en télétravail). Les résultats suggèrent que, sans aucune intervention de politique publique, jusqu'à $38 \%$ des entreprises seraient confrontées à un déficit de liquidité 10 mois après la mise en œuvre des mesures de confinement. En comparant l'impact de différentes politiques (report d'impôt, moratoire sur la dette et soutien au paiement des salaires), l'analyse montre que le soutien du gouvernement pour alléger la masse salariale est l'outil le plus efficace pour réduire les pénuries de liquidités, suivi par des politiques de moratoire sur la dette. Enfin, le document se penche sur les politiques du marché du travail et compare le rapport coûtefficacité des programmes de travail à court-terme et de subventions salariales et met en évidence que leur relative efficacité dépend de leur conception.

Classification JEL : D22, D24, J38, H81.

Mots-clés: COVID-19, liquidité, cash, dispositifs de maintien de l'emploi. 


\section{Table of contents}

Liquidity shortfalls during the Covid-19 outbreak: assessment and policy responses

1. Introduction

2. An empirical assessment of firms liquidity shortages during the COVID-19 outbreak 7

2.1. Size and dynamics of the economic shocks

2.2. Methodology to evaluate firms' liquidity position during the COVID-19 crisis

2.3. Simulation results

3. Public policies to reduce liquidity shortages and curb bankruptcy risk 13

3.1. A stylized comparison of policies impact

3.2. Zooming in on the effects of labour market policies on the share of firms facing liquidity shortfalls

4. Conclusion

\section{Tables}

Table A. 1 Detailed dynamic of the three alternative revenues shock scenarios

\section{Figures}

Figure 1. Liquidity shortfalls without government intervention

Figure 2. Liquidity shortfalls without government intervention: solvency, collateral availability and indebtedness 12

Figure 3. Liquidity shortfalls without government intervention: large heterogeneity across sectors 13

Figure 4. The impact of policies - downside scenario $\quad 15$

Figure 5. The impact of policies - upside scenario 16

Figure 6. Firms' labour cost, replacement rates, fiscal costs of stylized STW and WS schemes 17

Figure 7. The simulated reduction in firms facing liquidity shortfalls due to STW and WS 18

\section{Boxes}

Box 1. Main findings

Box 2. Measures adopted in OECD countries to support workers and firms in the wake of the COVID-19 crisis 14 Box 3. A stylised comparison of STW and WS schemes 


\title{
Liquidity shortfalls during the Covid-19 outbreak: assessment and policy
} responses

\author{
By Lilas Demmou, Guido Franco, Sara Calligaris and Dennis Dlugosch ${ }^{1}$
}

\section{Introduction ${ }^{2}$}

1. The health crisis caused by the COVID-19 outbreak in the beginning of 2020 has led public authorities to take unprecedented measures to contain the propagation of the virus. Administrative business shutdowns, quarantines and restrictions on mobility and social contact have had a severe negative impact on our economies. Annual growth of real GDP in OECD countries in 2020 is projected to contract by $-5.5 \%$, the largest annual decline of GDP in the history of the OECD (OECD, 2020a). While the economic impact of the COVID-19 pandemic was particularly pronounced in sectors that require close personal contact, e.g. events and recreation and accommodation and food sectors, sales across nearly all sectors plummeted throughout 2020 (OECD, 2020a). Nevertheless, financial commitments with respect to suppliers, employees, lenders and investors remain, depleting liquidity buffers of firms. The large number of firms that are simultaneously affected constitutes a major challenge. Some producers, e.g. of intermediate goods or services, experienced a drop in sales even if confinement measures do not require them to shut down. Since several firms along the same supply chains may face liquidity shortfalls, trade credit losses may increase, further adding to cash flow pressures.

2. The liquidity crisis could turn into a global corporate solvency crisis. With much less or no incoming revenues for an extended period of time and fewer options to deal with this shortfall, the long-term viability of firms is impaired. Survey evidence suggests that a significant number of firms, not limited to the most affected sectors, have not yet regained operating profitability in autumn 2020 (OECD, 2020a). This

\footnotetext{
${ }^{1}$ Corresponding authors: Lilas Demmou (lilas.demmou@oecd.org) and Guido Franco (guido.franco@oecd.org) from the Policy Studies Branch of the OECD Economics Department, Sara Calligaris (sara.calligaris@oecd.org) from the OECD Directorate for Science, Technology and Innovation and Dennis Dlugosch (dennis.dlugosch@oecd.org) from the Country Studies Branch of the OECD Economics Department. Section 3.2 benefited from the collaboration with Alexander Hijzen and Andrea Salvatori from the OECD Directorate for Employment, Labour and Social Affairs. The authors are grateful to Giuseppe Nicoletti (OECD Economics Department) for insightful suggestions and valuable discussions. The authors would like to thank for helpful comments Laurence Boone, Luiz de Mello, Alain de Serres, Isabell Koske, Christophe Andre, Sebastian Barnes, Aida Caldera Sánchez, Gabriel Machlica, Nigel Pain, Vincent Koen (all from the OECD Economics Department), Sarah Box, Chiara Criscuolo, Andrew Wyckoff, Dirk Pilat (all from the OECD Directorate for Science, Technology and Innovation), delegates to Working Party 1 and Working Party 3 of the Economic Policy Committee, to the Working Party for Industry Analysis of the Committee for Industry, Innovation and Entrepreneurship, and to the Committee for Industry, Innovation and Entrepreneurship. The authors also thank participants at the Economics department internal webinar, the Global Forum on Productivity webinar and the European Commission National Productivity Boards workshop. Sarah Michelson (also from the Economics Department) provided excellent editorial support.

2 This working paper updates and extends the OECD note "Corporate sector vulnerabilities during the COVID-19 outbreak: assessment and policy responses" (Tackling Coronavirus Series) published in May 2020. In particular, it uses more recent firm-level data and more refined, up to date, estimates with respect to the economic shock implied by the COVID-19 outbreak, while at the same time it deepens the analysis on job retention schemes.
} 


\section{6 | ECONKP(2021)1}

underlines that the risk of a large wave of corporate bankruptcies increases with the length of the crisis. A global corporate solvency crisis would have dramatic consequences on the real economy and significantly delay the recovery. Human and organisational capital would be eroded and may vanish with defaults of firms that prior to the virus outbreak were profitable and with healthy balance sheets. Global value chains would be severely disrupted if highly integrated firms have to exit the market. High uncertainty about the future course of the economy is reducing corporate investment and purchases of durable goods (OECD, 2020a). A potential widespread corporate solvency crisis would have serious long-term negative effects on our economies by dragging down employment, productivity, growth and well-being (Demmou et al., 2021).

3. The risk of a financial crisis remains high. Corporate defaults of a significant number of firms could undermine balance sheets of banks and institutional investors. Since many governments across OECD countries have temporarily lifted insolvency and banking regulations but will need to phase in these rules at some point, it will remain elevated in the near future. Distress in financial markets could dry up markets for debt and equity financing, and could feed a self-reinforcing downside spiral in the corporate sector, in turn significantly increasing the likelihood of a financial crisis. Moreover, bankruptcies across a wide set of firms combined with bailouts by government of systemic firms can decrease competition, with consequences for productivity growth down the line.

4. Awareness of these risks has led governments to adopt a range of emergency measures aimed at supporting firms' liquidity. Aside from monetary measures taken by central banks, fiscal interventions include direct financing of the wage bill through job retention schemes (e.g. short-term work and wage subsidy schemes), support to laid-off workers (e.g. extension of the coverage and increase in the replacement rate of unemployment benefits), tax deferrals, debt moratoria and extension of state loan guarantees.

5. This paper evaluates the extent to which firms experienced liquidity shortage using a cross-sector sample of almost one million European firms. Additionally, the paper discusses the pros and cons of different kinds of public support measures. The analysis focuses on the first-round effects of containment measures induced by the crisis, abstracting from the potential cascading effects via supply chains (including global value chains), financial interconnections between firms and financial distress in the banking system - other than those implicitly assumed in the size of the sectoral shocks - as well as from the structural adjustments that will be needed in a second phase of the response to the crisis. Based on illustrative assumptions regarding the evolution of sales and elasticities of costs to sales, the paper sheds light on the risk of corporate insolvency. ${ }^{3}$ Comparing the share of firms that would turn illiquid under a nopolicy change scenario and under policy intervention, results emphasizes the key role of policies to avoid massive unnecessary bankruptcies.

\footnotetext{
3 The methodology is similar to the one used by Schivardi and Romano (2020) for the case of Italy, and is based on a number of assumptions detailed in the remainder of the paper. It is also close in spirit to De Vito and Gomez (2020).
} 


\section{Box 1. Main findings}

- Without any policy intervention, corporate liquidity buffers would run out quickly: $18 \%$ of the firms in our sample would run out of liquidity after one month, $26 \%$ after two months and $30 \%$ after three months.

- Firms facing a high risk of liquidity shortfalls are mostly profitable and viable companies. However, a sizeable share of these firms do not have enough collateral to bridge a shortfall in liquidity with additional debt and/or are too highly leveraged to bridge the crisis through further bank loans. Moreover, the impact of the shock is highly heterogeneous across sectors and type of sectors: Hospitality, Entertainment and Transport sectors are the most severely hit, while intangible-intensive and low external finance dependent sectors are better positioned.

- Among the wide and complementary range of measures introduced by OECD countries, direct and indirect support to wage payments seems to be the most critical policy to curb the liquidity crisis, given the high share of wage costs in total spending.

- Adding up different policy measures (tax deferral, a debt-moratorium in all sectors facing a sales shock larger than $20 \%$, and wage subsidies at $80 \%$ of the wage bill in sectors facing a sales shock larger than $20 \%$ ), our simulation suggests that government interventions could have decreased the share of firms running out of liquidity from $26 \%$ to $7 \%$ compared to the non-policy scenario over a two months period.

- Imposing an identical fiscal cost for governments, the cost-effectiveness of short-term work (STW) and wage subsidy (WS) schemes in limiting firms' liquidity shortages depends on their design. In the absence of an eligibility threshold, STW schemes appear more cost-effective than WS. The higher the eligibility threshold, the more STW and WS schemes are found to achieve similar outcomes. Moreover, WS schemes have the potential to reduce even further the share of firms facing liquidity shortfalls, but at the cost of lower income protection for workers.

6. The remainder of the paper is organized as follows. Section 2 explains the details of empirical framework employed in the analysis. In Section 3, we discuss our findings and provide a wide range of robustness checks. Section 4 concludes.

\section{An empirical assessment of firms liquidity shortages during the COVID-19 outbreak}

\subsection{Size and dynamics of the economic shocks}

7. Measures on social distancing and mobility restrictions dramatically affect services involving direct contact between customers and providers, activities gathering people in public and private places, travelling, as well as non-essential manufacturing and construction activities involving close physical contact among workers. Activities that can be undertaken remotely or automatized are relatively less affected - to the extent that the supply chain is not broken and consumer demand can be maintained, at least in part. It follows that the decline in activity is assumed to be different across sectors but identical across countries. 


\section{8 | $\operatorname{ECONKP(2021)1}$}

8. The analysis covers all manufacturing and non-financial services sectors. ${ }^{4}$ The magnitude of the sales shock during confinement months is based on the first-round demand and supply shocks computed at a detailed sectoral level by del Rio-Chanona et al. (2020). ${ }^{5}$ To quantify the supply shock, the authors classify industries as essential or non-essential and construct a Remote Labour Index, which measures the ability of different occupations to work from home: the supply shock is not binding for essential industries, while inversely proportional to the capacity to telework for non-essential ones. To quantify the demand shock, they exploit a study of the potential impact of a severe influenza epidemic developed by the US Congressional Budget Office. In this note, we identify the resulting sector-specific - but country invariant - shock as the largest between the supply and the demand shock. ${ }^{6}$

9. Two alternative scenarios are considered with respect to the duration of the shock.

- An "upside" scenario, which foresees a sharp drop in activity lasting two months, followed by progressive but not complete recovery in the remaining part of the year. The recovery path is dependent on the initial shock, so that the most severely hit sectors face a larger absolute decline in revenues also after confinement, but the speed of the recovery is assumed for simplicity to be the same across sectors.

- A "downside" scenario, which overlaps with the "upside" scenario for the first seven months, but then embeds a second, relatively smaller outbreak from the eighth month onwards, accompanied by more limited lockdowns. ${ }^{7}$

- The current developments of the pandemic, characterized by localised outbreaks and uncertainty on the strength of virus resurgence suggest that the recession may be even deeper than modelled in the upside scenario but not as severe as in the downside scenario. It follows that the two scenarios could be more generally interpreted as a lower and an upper bound with respect to the magnitude of the shock. For the sake of exposition, the "downside" scenario is used as a baseline throughout the paper. ${ }^{8}$

\subsection{Methodology to evaluate firms' liquidity position during the COVID-19 crisis}

10. The approach relies on financial statements of non-financial corporations from the Orbis database, provided by the consulting firm Bureau Van Dijk, which collects balance sheets data on both listed and unlisted firms worldwide. To ensure firms' comparability across countries and sectors, the data are treated

\footnotetext{
${ }^{4}$ More specifically, it covers all economic sectors except the followings (Nace Rev.2 classification): agriculture (VA), mining (VB), financial (VK), public administration (VO), education (VP), human health (VQ) and activities of households and organizations (VT and VU).

${ }^{5}$ The full dataset on the confinement shock provided by del Rio-Chanona et al. (2020) can be found here.

${ }^{6}$ To see why this is the case, consider the following example. Due to confinement measures, a firm is able to produce $50 \%$ of its normal time output (e.g., supply shock). If the demand shock, due to changes in consumers' preferences, implies a $60 \%$ reduction in demand for the products of the firm, the firm will produce only what it is able to sell $-40 \%$ of its normal time output - and the demand shock is binding. On the contrary, if the reduction in consumers' demand is expected to be lower (e.g., $20 \%$ ), the firm will still produce at its maximum capacity during confinement and the supply shock is binding.

${ }^{7}$ See Table A.1 for the detailed dynamic of each scenario. The implications of the second outbreak characterizing the "downside" scenario are assumed to be smaller than those of the initial confinement period, taking into consideration that the rise in infections and the death toll are assumed to be less than in the earlier outbreak (e.g., increased hospital capacity and workers protection, better targeted social distancing measures).

${ }^{8}$ Results based on the "upside" scenario are not explicitly reported when they are quantitatively very similar, but are available upon request.
} 
according to Gal (2013) and Kalemli-Ozcan et al. (2015). The data also excludes very small firms - those having less than 3 employees - to avoid concerns related to the quality of the data. The final sample consists of 859,299 unique firms, operating in manufacturing but also non-financial business services industries. ${ }^{9}$

11. At present, Orbis is the largest cross-country firm-level dataset available and accessible for economic and financial research. However, it does not cover the universe of firms, and the extent of the coverage varies considerably across countries. ${ }^{10}$ To deal with these limitations, we focus on 14 relatively well-covered European countries, and purposely avoid in depth cross-country comparisons, as well as the provision of absolute numbers on the aggregate depth of the shortfall. ${ }^{11}$ Moreover, firms in Orbis are on average disproportionately larger, older and more productive than in the population, even within each size class. As these firms are on average healthier than their smaller, younger and less productive counterparts, the analysis is expected to deliver a lower bound for the liquidity shortages potentially affecting nonfinancial corporations.

12. The study assumes that the last available data for each firm (end of 2018) represents its financial situation in normal times with respect to its average revenue, operating expenses, debt payment and taxes. The economic shock from measures of social distancing is modelled as a change in firms' operating cash flow, resulting from the decline in sales and firms' limited ability to fully adjust their operating expenses. To reflect this adjustment capacity, elasticities of intermediate costs to sales and of the wage bill to sales are estimated by assuming, for simplicity, that they are identical and constant across countries and sectors. Each month, firms' shock-adjusted cash-flow (assuming zero investment spending) is determined as follows: ${ }^{12}$

$$
\begin{aligned}
\text { CashFlow }_{i t}= & \left(1-s_{s t}\right) * \text { Revenues }_{i}-\left(1-c * s_{s t}\right) * \text { Intermediate }_{i} \\
& -\left(1-w * s_{\text {st }}\right) \text { WageBill }_{i}-\text { Taxes }_{i}-\text { DebtPayments }_{i}
\end{aligned}
$$

where $s_{s t}, c, w$ refer, respectively, to the size of the shock in sector $s$ in month $t$, the elasticity of intermediates cost to sales, and the elasticity of wage bill to sales. Firms' sales, intermediate costs, wage bill, taxes and debt payments are annual values divided by 12 in order to obtain average monthly values. ${ }^{13}$

\footnotetext{
${ }^{9}$ See Table A.3 for firm-level basic descriptive statistics.

${ }^{10}$ For a detailed discussion of Orbis coverage and representativeness, see Bajgar et al. (2020).

${ }^{11}$ Countries included in the sample are: Belgium, Denmark, Finland, France, Germany, Hungary, Ireland, Italy, Poland, Portugal, Romania, Spain, Sweden and the United Kingdom. See Table A.2 for details on the number of firms by country.

12 The elasticity of costs to sales in the equation reflects the fact that a decrease in firm sales is partially passed over to suppliers. Therefore, the simple sum of the firms' total fall in sales would not represent correctly their total need for liquidity. Notice that it is unclear how the inclusion of taxes may inflate or deflate the impact of the crisis. On the one side, it is likely that following a drop in sales, the amount of tax payed will be lower following the crisis. On the other side, without any policy action, firms are expected to pay taxes computed for a normal year.

13 The role played by trade credit and inventories is not taken into account in this scenario due to current data availability, although they may be important drivers of firms' liquidity positions. The issue will be accounted for in future refinements of the analysis. However, notice that, though sizeable, the use of trade credit remains largely lower than the use of bank-based financing solutions (24\% against $70 \%$ according to ECB, 2010).
} 
13. The elasticities of intermediate inputs to sales and of the wage bill to sales are estimated through a panel regression analysis based on yearly data. ${ }^{14}$ The former is close to unity, while the latter is estimated around 0.4. As expected, these calculations suggest that firms have a higher ability to adjust their consumption of intermediary goods than labour. To take into account the fact that the ability to adjust is lower when looking at monthly rather than annual figures, in the spirit of Schivardi and Romano (2020), both elasticities are conservatively reduced to 0.8 and 0.2 , respectively.

14. Next, the liquidity available to each firm is calculated month by month as the sum of the liquidity buffer held at the beginning of the period and the shock-adjusted cash-flow, assuming no capital expenditures:

$$
\text { Liquidity }_{i t}=\text { Liquidity }_{i,(t-1)}+\text { CashFlow }_{i t}
$$

where Liquidity $_{i,(t-1)}$ refers to the liquidity remaining from the previous month and is equal to a firm's cash holdings in the first period.

15. Firms face liquidity shortages when they run out of cash and are unable to cover operating expenses, taxes due and costs of existing debt. By running this exercise month by month, we evaluate the share of firms that may have entered a liquidity crisis following the introduction of confinement measures. ${ }^{15}$ Importantly, this approach relies on the following assumptions:

- The sectoral distribution of the shock is assumed to be the same across countries. ${ }^{16}$

- The capacity of firms to adjust their operating expenses following an adverse shock is expected to be the same across countries, sectors and firms.

- Firms are not able to tap into external sources of working capital (e.g. short-term bank loans, trade credit) when facing a liquidity shortfall.

\subsection{Simulation results}

\subsubsection{The risk of liquidity shortages is high for a large portion of firms}

16. The main results (Figure 1) suggest that in the absence of government intervention, firms in our sample would run out of liquidity relatively quickly: after one month, $18 \%$ of firms would have depleted liquidity buffers, $26 \%$ after two months, and $30 \%$ after three months. The share of firms facing liquidity shortfall could even lift to $34-38 \%$ by the end of 2020. It is important to stress again that these estimates are likely a lower bound given the sample bias towards healthier firms and the conservative assumptions made on elasticities. At the same time, to reflect the decision of most governments to provide cross-cutting support to firms in the first stage of the crisis, the simulations include also firms that would have faced liquidity shortfalls even in the absence of the COVID-19 epidemic. After one month, the share of firms

\footnotetext{
${ }^{14}$ More specifically, we regress the growth in revenues on either the growth of intermediates cost or the growth of the wage bill, controlling for all shocks at the country-sector level and for firms' time-invariant characteristics (i.e., by including country by sector by year and firm fixed effects).

${ }^{15}$ The exercise models liquidity shortfalls and does not allow to determine solvency of firms endogenously, i.e., within the framework of this model. Further, given that the sample also consists of non-listed firms, it is not possible to determine the cost of equity due to the absence of market prices for equity of non-listed firms. Subsequently, the analysis refrains from any implications on firm value, e.g., based on discounted future profits.

16 The COVID-19 crisis impact is certainly different across countries depending on the distribution of firms according to their liquidity positions, the type of social distancing measures introduced in each country, the input-output linkages and the country-specific policy responses. Looking deeper at those issues is something left for future research.
} 
facing liquidity shortfalls in normal times ranges between $1.5 \%$ and $7 \%$, depending on their ability to adjust when dealing with negative cash flows; it follows that, even when considering the $7 \%$ upper bound estimate, the COVID-19 crisis would imply an almost threefold increase in the share of firms experiencing liquidity shortages after one month.

17. Overall, given that running into a liquidity shortfall may trigger bankruptcy of otherwise profitable firms, our findings emphasize that this firm-specific shock could have large and permanent adverse effects.

\section{Figure 1. Liquidity shortfalls without government intervention}

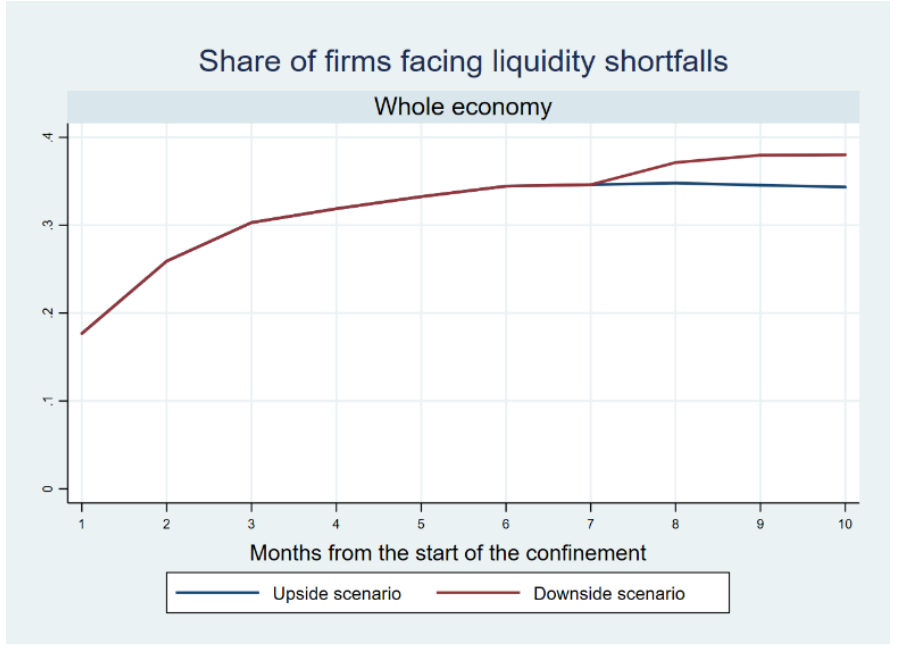

Note: The figure shows the share of firms facing liquidity shortfalls over the whole sample, considering two alternative scenarios: upside (blue line), and downside (red line) scenario. The upside scenario foresees a sharp drop in activity lasting two months, followed by progressive but not complete recovery in the remaining part of the year. The downside scenario overlaps with the upside scenario for the first seven months, but then embeds a second, relatively smaller, outbreak from the eighth month onwards.

Source: OECD calculations based on Orbis $§$ data.

\subsubsection{Firms facing liquidity shortages are often solvent, but their access to additional debt financing may be limited due to low collateral}

18. Firms may run into a liquidity shortfall if their assets are not liquid enough to cover current expenses. However, they may still be solvent if the value of their assets is larger than the value of their liabilities or, equivalently, if they have collateral to pledge in order to obtain additional bank financing (Figure 2, left panel). ${ }^{17}$ Only a relatively small share of firms (around 11\%) among those expected to face liquidity shortfalls would be close to insolvency when evaluating their overall net worth. At the same time, even though solvent, they might have difficulties in accessing new bank financing: around $27 \%$ of firms turning illiquid during the confinement would lack the collateral to tap into additional debt financing. Moreover, a decrease in valuations of assets during the confinement would decrease the value of firms' potential collateral, thus further impairing their ability to obtain external funding. Similarly, and despite its development over the last two decades, also market-based financing from non-banks might be affected, as the price of traded debt rises in periods of acute market stress, and so does the business' cost of financing (OECD, 2020b). Finally, highly-leveraged firms tend to have a higher probability to face liquidity shortages. Combined with the high uncertainty about sales and other incoming cash flows in the near future, this makes obtaining new loans more difficult (Figure 2, right panel).

${ }^{17}$ Collateral is proxied by the difference between fixed assets and non-current liabilities. 
Figure 2. Liquidity shortfalls without government intervention: solvency, collateral availability and indebtedness

Share of firms facing liquidity shortfalls, but solvent or with collateral Downside scenario

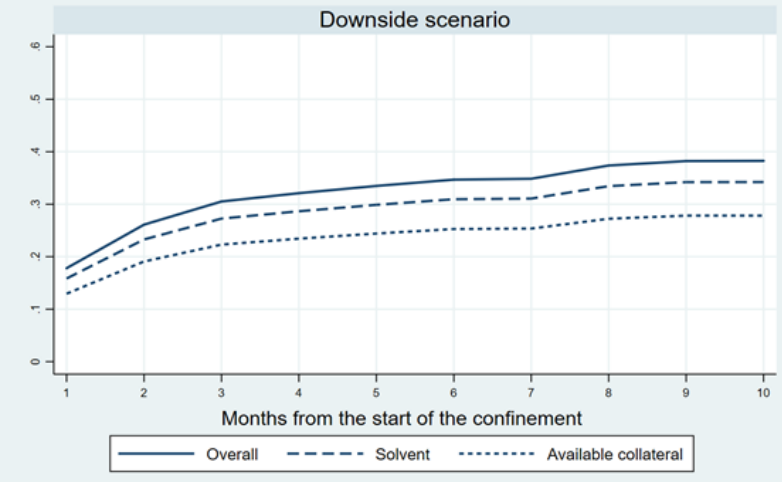

Share of firms facing liquidity shortfalls, by indebtedness level Downside scenario

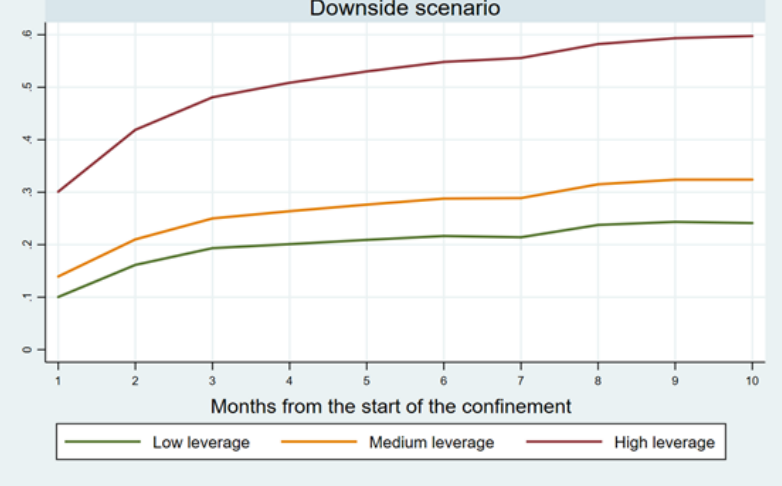

Note: The left panel plots the share of firms facing liquidity shortfalls: overall (solid line); but still potentially solvent, i.e., if the value of their assets is larger than the value of the liabilities (dashed line); having collateral to pledge to obtain additional bank financing, i.e., if the value of their fixed assets is larger than the value of their non-current liabilities (dotted line). The right panel plots the share of firms facing liquidity shortfalls by indebtedness level, i.e.: belonging to the lowest $1 / 3$ of the leverage distribution within each 2-digit (Nace Rev.2) sector (green line); belonging to the middle $1 / 3$ of the leverage distribution within each sector (orange line); belonging to the highest $1 / 3$ of the leverage distribution within each sector (red line). Leverage is measured as the ratio between financial debt (short- plus long-term debt) and total assets. The calculations are based on the downside scenario. The downside scenario foresees a sharp drop in activity lasting two months, a progressive but not complete recovery in the next seven months and a second, relatively smaller, outbreak from the eighth month onwards.

Source: OECD calculations based on Orbis $®$ data.

\subsubsection{The effect of the crisis on firms liquidity is heterogeneous across sectors}

19. The impact of the COVID-19 outbreak on firms' liquidity is highly heterogeneous sectors. Without policy intervention, more than half of firms are predicted to experience liquidity shortages in the "Accommodation and food service activities", "Transports" and "Arts, entertainment and recreation" sectors; by contrast, the "Utilities", "Information and communication" and "Professional services" sector display a share of illiquid firms consistently below $20 \%$ in our sample (Figure 3, left panel). Moreover, as shown in the right panel of Figure 3, firms in intangible-intensive or low external finance dependent sectors appear better positioned to weather the crisis compared to those in sectors intensive in tangible assets or highly dependent on external financing. This is consistent with their specific financial structure, often characterized by larger cash buffers in normal time, as well as with the diverse ability of intangible-intensive firms to rely on innovative technologies and teleworking arrangements, thus being exposed to a less severe sales shock. 


\section{Figure 3. Liquidity shortfalls without government intervention: large heterogeneity across sectors}
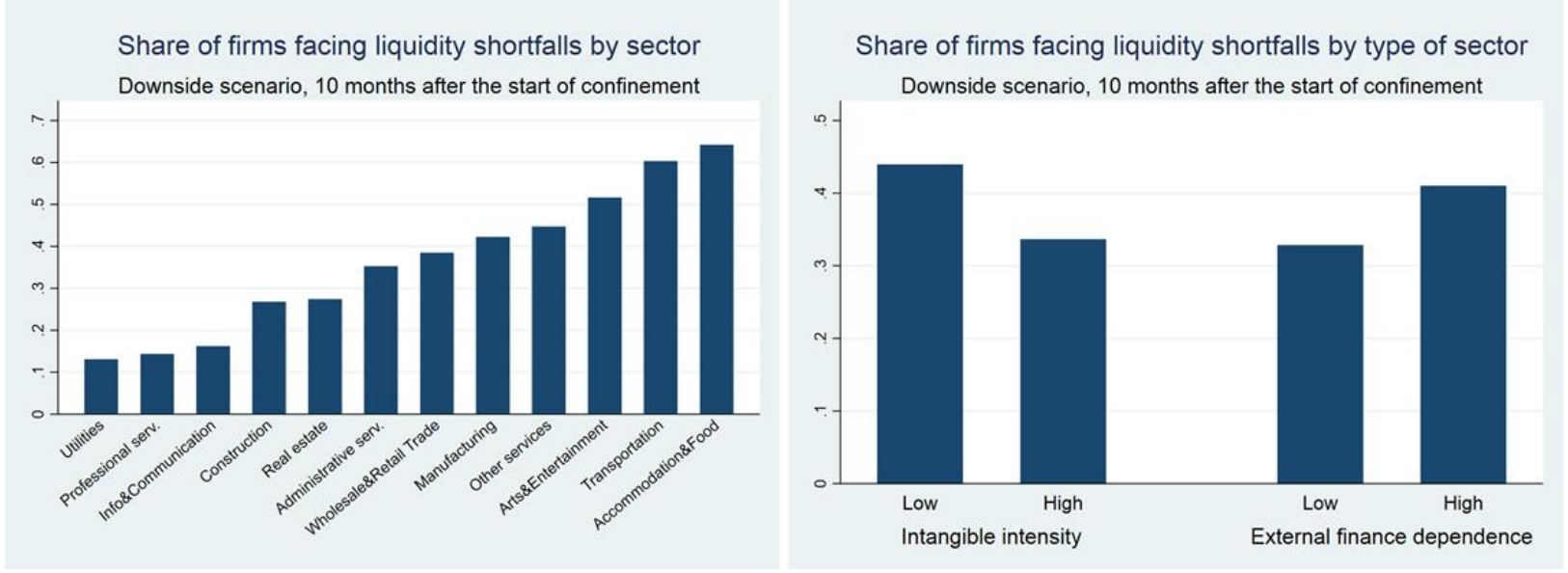

Note: The figure shows the share of firms facing liquidity shorffalls after 10 months since the start of confinement measures by 1-Digit Nace Rev2 sectoral classification in the left panel and either by sectoral intangible intensity or by sectoral external finance dependence in the right panel. Sectoral intangible intensity and external finance dependence are computed following Demmou et al. (2019). Both panels refer to the downside scenario, which foresees a sharp drop in activity lasting two months, a progressive but not complete recovery in the next seven months and a second, relatively smaller, outbreak from the eighth month onwards. Notice that, for the sake of exposition, the y-axis scale varies among panels.

Source: OECD calculations based on Orbis® data.

\section{Public policies to reduce liquidity shortages and curb bankruptcy risk}

20. While the above findings are based on several assumptions and must be interpreted with some caution, they underline the merit of swift and decisive public intervention to avoid potential bankruptcies of otherwise healthy companies. Such intervention has been crucial to prevent that the temporary shock implied by the COVID-19 crisis permanently scars the corporate landscape, with serious consequences for the shape of the recovery and long-run growth prospects.

\subsection{A stylized comparison of policies impact}

21. Countries have introduced a wide range of measures to help firms dealing with the disruptions associated with COVID-19 (see Box 1). The simple accounting model described above is used to shed light on the impact of stylised policy interventions in three areas: ${ }^{18}$

- Deferral of tax. To support business during the epidemic, several countries have introduced tax deferrals. The tax deferral is modelled as the moratorium of the (hypothetical) monthly tax payments for the entire period considered (10 months). ${ }^{19}$

- Financial support for debt repayment. A large number of countries have also established legislative frameworks that temporarily allow firms to postpone their debt payments or alternatively, that offer State guarantees to facilitate access to short-term debt facilities. The potential impact of such

\footnotetext{
18 Note that in many countries policy responses may depend on firms' characteristics, such as size, and may be targeted differently according to sectoral features (e.g., exposure to the shock). However, given that governments are continuously developing their actions, at this stage it would be very difficult to quantify these heterogeneities with the information available.

19 It is worth noting that the deferral of tax might not have a large impact in a period where sales and profits are expected to be limited. Moreover, due to data availability, the analysis does not allow distinguishing different types of taxes.
} 
policies is modelled as a moratorium on short-term debt over the whole period in all sectors facing an initial sales shock larger than $20 \%$ during the first months of confinement.

- Temporary support to wage payments. A critical response to avoid widespread liquidity shortfalls consists of relaxing firms' financial commitments vis-à-vis their employees. Schemes such as a shortening of working time, wage subsidies, temporary lay-offs and sick leave have been introduced across countries, though in different combinations. All these measures reduce the wage bill firms have to pay. The labour support is modelled in two alternative ways: as an unconditional reduction of the monthly wage bill by $80 \%$ in all sectors facing a sales shock larger than $20 \%$ in the given month (e.g. wage subsidy scheme);20 as a support adjusted to the sectoral size of the shock and modelled through an increase to 0.8 of the elasticity of wage bill to sales (e.g. short-term work scheme). ${ }^{21}$ Notice that, under these assumptions, the two schemes entail different fiscal costs, with the short-term work scheme being less costly. Further, it is assumed that firms receiving support could not adjust workers earnings (e.g. firm top-up).

\section{Box 2. Measures adopted in OECD countries to support workers and firms in the wake of the COVID-19 crisis}

This box provides some examples of concrete measures OECD economies have implemented to support workers and companies at the beginning of the COVID-19 crisis.

Many OECD countries subsidise temporary reductions of hours worked in firms impacted by confinement measures. Austrian authorities, for example, support wages of workers in all sectors (except public service) of up to $70 \%$, in some exceptions up to $90 \%$, of the net salary in the November version of their short-time working scheme. The scheme allows to temporarily reduce the number of hours worked to zero, however, workers are required to work at least $20 \%$ of the working-time calculated over the full period in which the firms receives support through the short-time working scheme. The maximum period of support through short-term work is currently six months. The total amount taken over by the government varies with the gross salary.

Another set of measures consists of financial support for debt repayment. The Business Credit Availability Program (BCAP) in Canada, for example, supports access to financing during the COVID19 crises in various ways for firms across all sectors. Small businesses with up to CAD 1.5 million in total payroll costs in 2019 can receive interest-free loans up to CAD 40000 to cover operating costs (e.g. utilities, payroll, rent, debt service). These loans are fully guaranteed by the public. One fourth of the loan is forgiven if it is repaid by the end of 2022. If not, the loan will be automatically converted to three year loan at 5 per cent interest. Larger businesses can tap additional bank-based debt financing up to a total loan amount of CAD 6.25 Million, guaranteed to up to $80 \%$ by the public. These loans comprise only operating costs and cannot be used to fund dividend payments, share repurchases and other shareholder payments, increases in the compensation of executives or to refinance or repay existing debt.

Besides guaranteed loans, a couple of OECD countries directly subsidize firms' operating costs. Norway, for example, compensates Norwegian firms that suffered significant losses of turnover due to the COVID-19 crisis. All taxable registered companies in most sectors (except oil and gas, financial

\footnotetext{
${ }^{20}$ According to the OECD tracker the amount of labour subsidy varies across countries between 60 to $100 \%$ of gross wage, with a great majority of countries providing a support ranging from $70 \%$ to $90 \%$. This is the case for instance of Canada, Denmark, France, Netherland, Norway, Sweden and Japan.

${ }^{21}$ Indeed, in some countries the support is targeted only to firms experiencing a sizeable shock in their activity. The elasticity implies that the support is ranging from $40 \%$ to $80 \%$ depending on the size of the sectoral shock.
} 
industry, utilities) in Norway are eligible for this compensation under the condition that they were not already in financial distress before the crisis.

Temporary reductions in tax rate or deferrals of tax or social security payments constitute a further possibility to prevent liquidity shortfalls in the short-term. Korea has introduced a temporary special tax reduction for SMEs located in Corona-related disaster areas until the end of 2020. VAT payments by small businesses, i.e. businesses with less than KRW 80 million in annual revenues, are reduced as well until the end of 2020. Small businesses can further defer taxes up to 1 year and social security contributions up to three months.

Several OECD economies have complemented subsidies, loan guarantees and tax-related measures with "soft" tools to ensure repayments and to safeguard operating cash flow. In France, for example, authorities actively support mediation over credit conflicts between private parties with a free, fast and reactive mediation service. French SMEs can also mobilise credit mediation if they experience difficulties with one or more financial institutions. Furthermore, the Ministry of Economy and Finance has set up a crisis unit dedicated at inter-company credits to monitor the use of trade credit.

22. Figure 4 and Figure 5 illustrate the extent to which each measure curbs the risk of a liquidity crisis compared to the no-policy intervention scenario. In particular, they look at the two alternative temporary supports to wage payments under the downside scenario (Figure 4), and under the upside scenario (Figure 5). Tax deferral has the lowest impact on firms' liquidity positions, followed by debt moratorium policies. Overall, subsidies to the wage bill seem to be the most powerful measure (yet potentially costly), in line with the fact that wages and salaries are often the most relevant component of operating expenses. Adding up the three different measures, public intervention after two months, for instance, would decrease the number of firms running out of liquidity from $26 \%$ to $7 \%$ when assuming a wage subsidy scheme that implies a reduction of the wage bill by $80 \%$ in all sectors facing a sales shock larger than $20 \%$ (left panel), and from $26 \%$ to $13 \%$ when assuming a short-term work scheme, which is conditional on the shock's size (right panel).

\section{Figure 4. The impact of policies - downside scenario}

Share of firms facing liquidity shortfalls Downside scenario, wage subsidy scheme

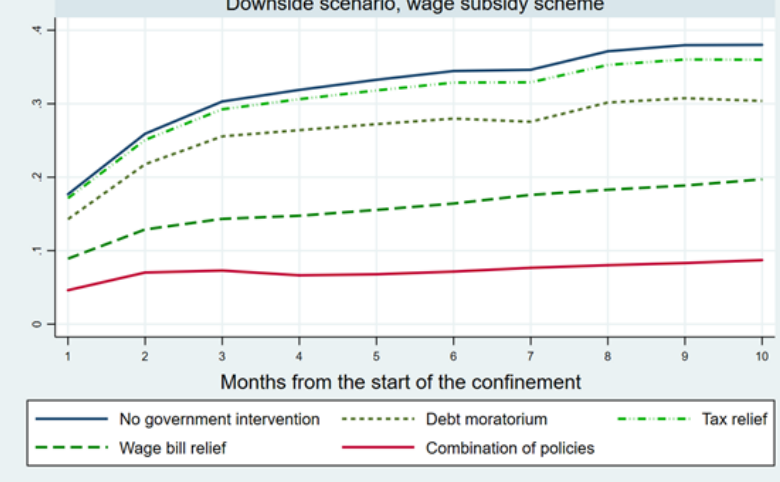

Share of firms facing liquidity shortfalls Downside scenario, short-term work scheme

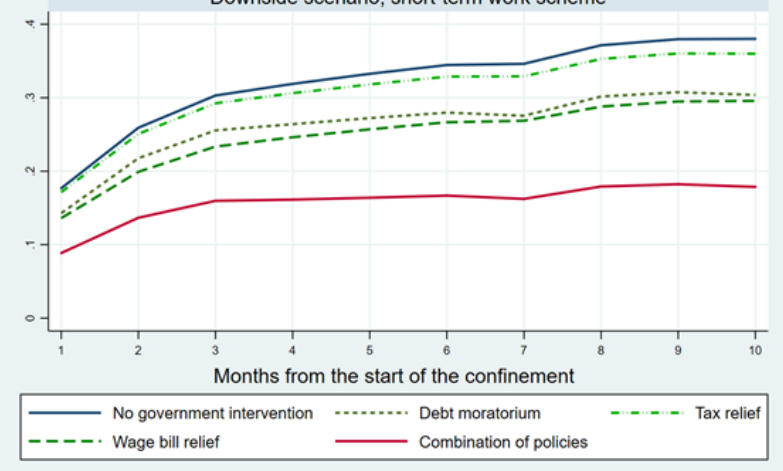

Note: The figure shows the share of firms facing liquidity shortfalls: in absence of policy intervention (blue solid line); in case of deferral of tax (green dash-dotted line); in case of a moratorium on short-term debt in all sectors facing an initial sales shock larger than $20 \%$ (green dotted line); in case of temporary support to wage payments (green dashed line); a combination of all the previous measures (red solid line). Shortterm debt is defined as the amount of financial liabilities that are due within the year. The temporary support to wage payments (green dashed line) is assumed to be: in the left panel, a wage subsidy scheme, implying a reduction of the wage bill by $80 \%$ in all sectors facing a sales shock larger than 20\%; in the right panel, a short-term work scheme, which is conditional on the sectoral size of the shock and modelled through an increase to 0.8 of the elasticity of wage bill to sales. The calculations are based on the downside scenario. The downside scenario foresees a sharp drop in activity lasting two months, a progressive but not complete recovery in the next seven months and a second, relatively smaller, outbreak from the eighth month onwards.

Source: OECD calculations based on Orbis $®$ data. 
Figure 5. The impact of policies - upside scenario

Share of firms facing liquidity shortfalls Upside scenario, wage subsidy scheme

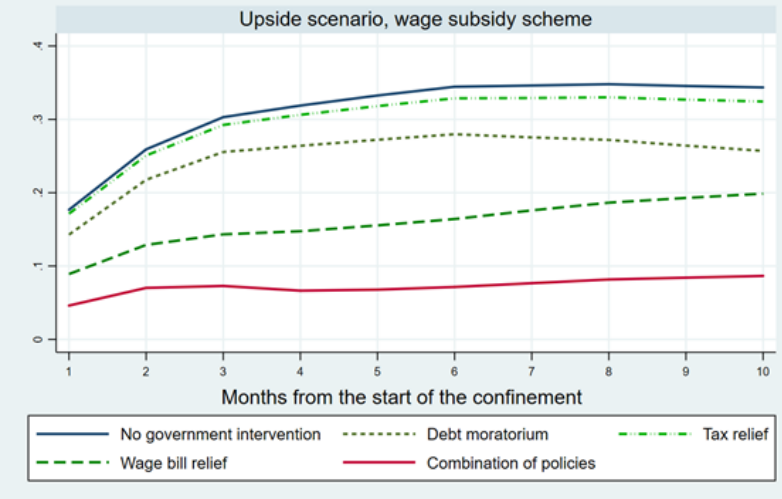

Share of firms facing liquidity shortfalls Upside scenario, short-term work scheme

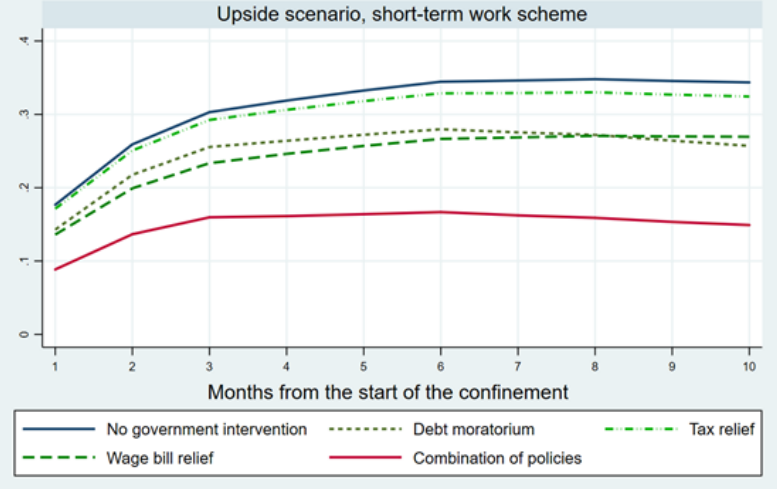

Note: The figure shows the share of firms facing liquidity shortfalls: in absence of policy intervention (blue solid line); in case of deferral of tax (green dash-dotted line); in case of a moratorium on short-term debt in all sectors facing an initial sales shock larger than $20 \%$ (green dotted line); in case of temporary support to wage payments (green dashed line); a combination of all the previous measures (red solid line). Shortterm debt is defined as the amount of financial liabilities that are due within the year. The temporary support to wage payments (green dashed line) is assumed to be: in the left panel, a wage subsidy scheme, implying a reduction of the wage bill by $80 \%$ in all sectors facing a sales shock larger than 20\%; in the right panel, a short-term work scheme, which is conditional on the sectoral size of the shock and modelled through an increase to 0.8 of the elasticity of wage bill to sales. The calculations are based on the upside scenario. The upside scenario foresees a sharp drop in activity lasting two months, followed by progressive but not complete recovery in the remaining part of the year.

Source: OECD calculations based on Orbis® data.

\subsection{Zooming in on the effects of labour market policies on the share of firms facing liquidity shortfalls}

23. In this section, the model outlined in Section 2 is extended to evaluate the relative effectiveness of job retention schemes at reducing the share of firms facing liquidity shortages. In particular, the analysis focuses on the cost-effectiveness of two frequently employed schemes, the Short-Term Work scheme (STW) and the Wage Subsidy (WS) scheme 22 To do so, we impose fiscal neutrality between the two schemes, which is achieved by ensuring that the surface under the cost curves for the government are identical under the various schemes. In particular, a $40 \%$ wage subsidy comes at a similar cost to the government as the STW scheme based on replacement rate of $80 \%$ for hours not worked, but under the assumption that government support is uniformly distributed across firms experiencing a decline in revenues above a certain threshold (i.e. $20 \%$ as in previous section settings). It is further assumed that reductions in sales translate one-to-one in reductions in working time, while employment remains constant.

24. The likelihood that a firm becomes illiquid is affected by the way the burden of the adjustment of working hours is shared between government, firms and workers. An increase in the government support or a decline in wages both contribute to reduce the risk of liquidity shortage. By contrast, the payment of non-worked hours has the reverse effect. To disentangle the direct effect of the government support on the share of jobs in firms with liquidity problems from the indirect effect that is due to the adjustment in worker earnings, two sets of simulations are conducted:

- Firms fully top up subsidies to maintain worker earnings despite a reduction in working time. Under this scenario, wages do not adjust, which isolates the direct effect of government support to reduce the share of illiquid firms.

\footnotetext{
22 In this section, we ignore the effect of debt moratorium and tax deferral to focus on labour market policies.
} 
- Firms do not top up subsidies in the case of reduced working hours, implying that workers get paid only for hours worked or, alternatively, the subsidy if earnings are too low. Under this scenario, the share of illiquid firms is further reduced by the extent of the worker adjustment.

- The details about the way government, firms and workers adjust to not worked hours on our stylised STW and WS schemes are explained in Box 3.

\section{Box 3. A stylised comparison of STW and WS schemes}

In the stylised STW scheme, workers receive a compensation of $80 \%$ of their wage for any hour not worked. Absent of top-ups by firms, employers bear the full costs of any hours worked, but none of the costs of hours not worked. Consequently, labour costs decline towards zero at the same rate as hours worked (Panel A of Figure 6), while the cost of this subsidy for the government increases. Total earnings for workers decline (Panel B and C of Figure 6) with the number of hours not worked. If firms top-up the subsidy in order to avoid any wage losses for workers, earnings are unaffected by the reduction in working time, while firms have to contribute $20 \%$ of the cost of hours not worked.

Under the WS scheme, it is assumed that employers receive a subsidy equal to $40 \%$ of usual wage bill, irrespective of the reduction working time (Panel B of Figure 6. In the absence of firm top-ups, the reduction in labour costs for firms is equal to the subsidy (Panel A); firms' labour costs are zero if working hours are reduced by more than $60 \%$. Employees do not receive any compensation for hours not worked unless earnings for hours worked fall below the level of the subsidy (Panel C). With full top-ups, workers earnings are unaffected by the reduction in working time, while firms cover the costs of hours reductions beyond $60 \% .^{1}$

\section{Figure 6. Firms' labour cost, replacement rates, fiscal costs of stylized STW and WS schemes}

$\%$ of normal labour costs / earnings by \% reduction in working time in the absence of top-ups by firms
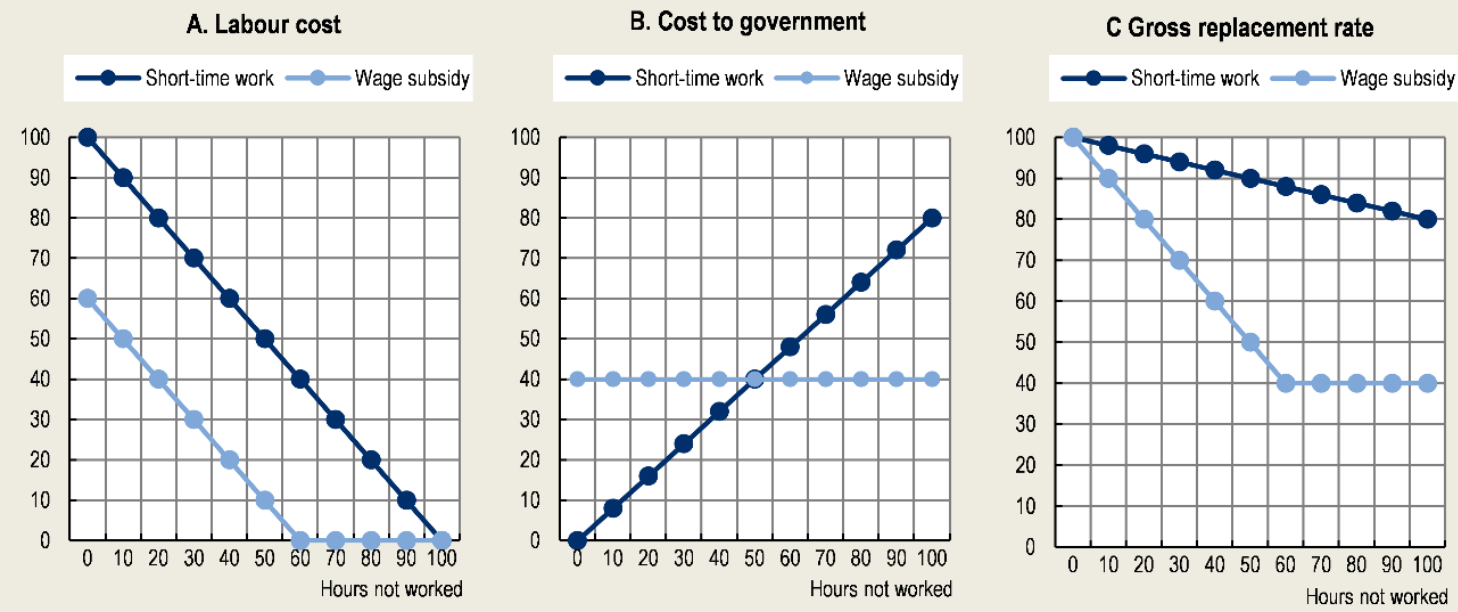

Source: OECD (2020c).

25. When firms top-up the subsidy in order to compensate for any wage decline, STW and WS schemes subsidies are found to be similarly effective at addressing firms' liquidity shortages (Figure 7, left panel). This is mainly because granting a wage subsidy to firms experiencing a large decline in sales ensures that government support is not too largely dispersed and broadly targets the same set of firms 
benefitting from STW; indeed, the removal of the threshold to access WS schemes would make STW relatively more cost-effective. ${ }^{23}$

26. In the absence of top-up by employers, WS schemes potentially allow for larger reductions in labour costs for firms compared to STW, at the cost of providing weaker income protection for workers on reduced working hours (Figure 7, left panel). Indeed, the share of firms facing liquidity shortfalls decreases considerably more under the WS stylised scheme (e.g. around 18 percentage points) rather than under the STW scheme (e.g. up to 12 percentage points). However, these estimates capture both the direct effect of the support and the indirect adjustments to workers earnings. The right panel of Figure 7 further illustrates how the burden of the adjustment is distributed between workers and government compared to a market adjustment scenario. The STW scheme envisages the same worker adjustment as in the market scenario and thus the 12 percentage points reduction in the share of illiquid firms is fully driven by the contribution of government support; on the contrary, government contributes only for 10.5 percentage points in the reduction associated with the WS schemes and the remaining 7.5 percentage points are due to worker adjustment. As a result, in the absence of firms top-up, STW work schemes appear slightly more cost-effective. ${ }^{24}$

\section{Figure 7. The simulated reduction in firms facing liquidity shortfalls due to STW and WS}

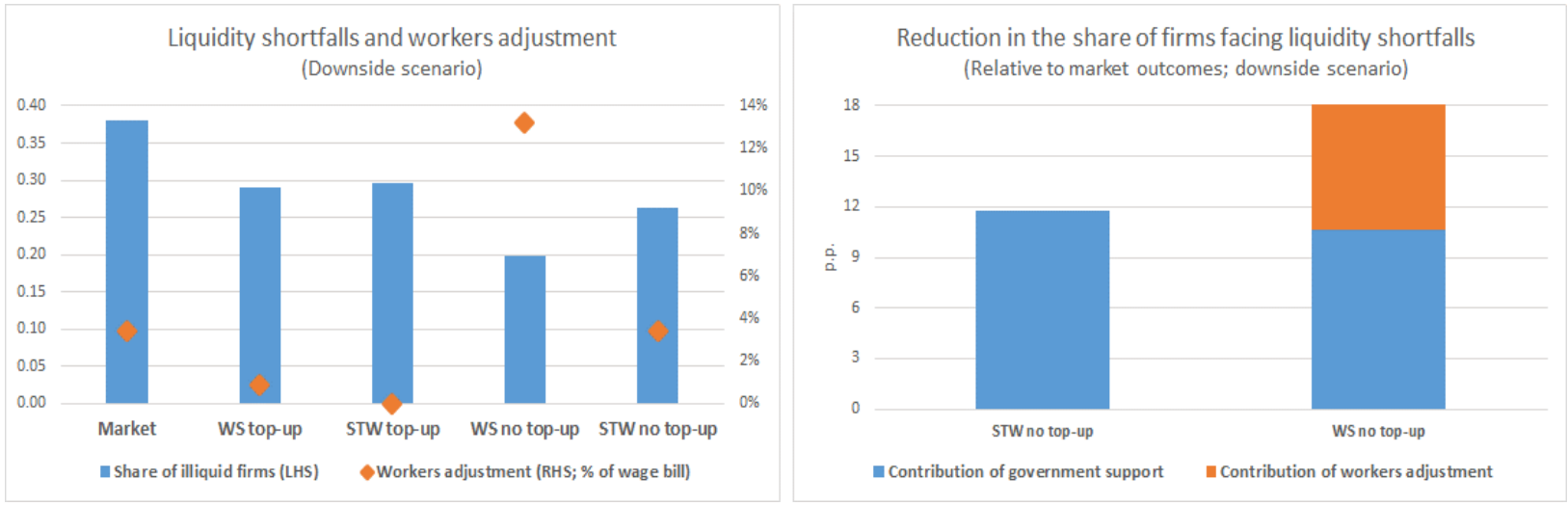

Note: The left panel shows the share of firms facing liquidity shortfalls (blue bars, left y-axis) and the percentage of foregone earnings for workers (orange rhombus, right y-axis) 10 months after the start of the confinement: in absence of policy intervention ("Market"); in case of a wage subsidy around $40 \%$ of the total wage bill for firms experiencing a decline in sales larger or equal to $20 \%$ and firms topping-up the subsidy to compensate wage decline ("WS top-up"); in case of a short-term work scheme based on replacement rate of $80 \%$ proportional to the sectoral size of the shock and firms topping up to compensate wage decline ("STW top-up"); in case of a wage subsidy around $40 \%$ of the total wage bill for firms experiencing a decline in sales larger or equal to $20 \%$ with no top-up from firms ("WS no top-up"); in case of a short-term work scheme based on replacement rate of $80 \%$ proportional to the sectoral size of the shock and with no top-up from firms ("STW top-up"). Government support to relieve wage bills is modelled to ensure fiscal neutrality across the different schemes. The right panel disentangles the contribution of government and workers adjustment in the reduction of the share of illiquid firms in the no top-up setting for both STW and WS, relative to market outcomes. Both panels refer to the downside scenario, which foresees a sharp drop in activity lasting two months, a progressive but not complete recovery in the next seven months and a second, relatively smaller, outbreak from the eighth month onwards.

Source: OECD calculations based on Orbis ${ }^{\circledR}$ data.

\footnotetext{
${ }^{23}$ Detailed calculations available upon request. Under the WS scheme with firms top up and no threshold, the share of firms facing liquidity shortages would rise to $32 \%$ compared to the $29 \%$. Indeed, the lower the threshold, the higher the number of eligible firms and lower the level of the wage subsidy for each firm at a given overall fiscal cost.

24 It is worth noticing that the exercise is stylized in nature and aims at illustrating the adjustment mechanisms related to STW and WS schemes; the several ways in which STW and WS could be designed may have a relevant impact on their cost-effectiveness (e.g. extent of wage adjustment, eligibility thresholds). Moreover, the stylised comparison and the simulations below abstract from the difference in labour costs for firms and gross wage for workers due to the presence of employer social security contributions.
} 


\section{Conclusion}

27. This paper examines the vulnerability of non-financial corporations in the context of the COVID-19 crisis. The large decline in activity implied by confinement measures generated widespread liquidity shortfalls, potentially leading to a wave of defaults of otherwise viable businesses. According to the exercise performed, without policy actions, after one month, $18 \%$ of firms face a liquidity shortage and up to $30 \%$ of them after three months.

28. Policymakers have taken a wide range of actions to mitigate the risk of a liquidity crisis, including policies aimed at smoothing financial obligations over time (e.g. tax deferral, extending loan maturities, temporarily suspending debt repayment) but also direct support involving a mutualisation of losses (e.g. liquidity injection through equity participation, direct subsidies based on past sales, subsidies for maintaining employment, grants). ${ }^{25}$ This paper emphasizes the need for a massive public intervention; given the composition of firms' expenditures, policies aimed at relieving wage bills are of paramount importance to help firms addressing the liquidity shortfall. However, several challenges related to the design of policies are left unexplored. In particular:

- Country-specific dimensions. Country-specific institutional settings may shape the extent and the efficiency of the policy response. Given the importance of labour market policies highlighted in the paper, it is likely that countries with already well-developed labour market support schemes have been able to provide a quick response with less distortive effects. For instance, short-time work schemes are already well-developed in many OECD countries, in particular in Germany and Austria, and have already proven to be efficient in time of crisis. Generous unemployment benefits schemes in France and Denmark have helped curb the adverse effect of a shock.

- Conditionality. Certain countries have conditioned loans forbearance and wage subsidies on the actual reduction in payroll, with the requirement to be used to cover fixed costs only or to rehire fired employees after the crisis. For example, in Denmark, firms only qualify for the wage compensation scheme if they promise not to lay off workers for economic reasons during the COVID-19 crisis, and if they can pay the remaining $25 \%$ of the salary not covered by public subsidies. The design of transfers and subsidized loans to corporations should ensure that firms preserve jobs and that any funds are not used to boost CEO compensation or dividend payments, either through cash dividends or stock repurchases. The loan guarantees in Canada, for example, include a condition that allows businesses only to use guaranteed loans to cover operating costs, but exclude refinancing or repayment of debt or any corporate actions related to an increase in executive compensation or shareholder remuneration.

- Short-term versus medium-term policy answer. In many cases, given the need of an urgent policy response during the so-called "phase one" of the crisis, policy has not been particularly targeted in the short term. The analysis above illustrates the broad challenges and the impact of stylised and cross-cutting policy responses. Going forward, short-term, cross-cutting policies might need to be further refined and better targeted to ensure that public support does not contribute to resources misallocation, for instance by propping up unviable firms.

- Heterogeneity of the shock. Policies need to deal with the heterogeneous impact of the shock. Indeed, with economic activity recovering, firms will not be on the same foot to face the crisis other than for liquidity reasons; for instance, collateral availability could allow some firms to tap external finance while start-ups and intangible-intensive firms will be relatively disadvantaged. Meeting these challenges would require refining the measures over time.

\footnotetext{
25 See OECD (2020d) for more details on the implications of the crisis for firm ownership and bankruptcies, and OECD (2020e) for more details on equity injections and unforeseen state ownership of enterprises during the crisis.
} 
- New normal. The extent to which the COVID-19 crisis will disrupt the economies is still uncertain. In European countries a large set of policies, in particular in the labour market, is tailored on the principle to protect the pre-crisis allocation of resources. In other countries, like in the U.S., the adjustment largely hinges on payroll reduction via layoffs. The comparative evaluation of these approaches goes beyond the scope of this paper; yet, it is worth noticing that their relative efficiency during the recovery and beyond may be related to whether economies will structurally change coming out of the COVID-19 crisis. If so, as the demand for some sectors might decline for a long period, policy design should find a balance between preserving pre-crisis job matches and allowing new matches via job reallocation. Similarly, deferring tax and debt payment will lead to a surge of corporate debt from an already record high level. Structural change and prolonged sluggish demand in some sectors will also change firms' profitability prospects and ability to deal with those liabilities. Therefore, finding a balance between debt forbearance and bankruptcy procedures will be a critical challenge during the recovery. 


\section{References}

Bajgar, M., Berlingieri, G., Calligaris, S., Criscuolo, C., and J. Timmis (2020), "Coverage and representativeness of Orbis data", OECD Science, Technology and Industry Working Papers, No. 2020/06, OECD Publishing, Paris, https://doi.org/10.1787/c7bdaa03-en.

del Rio-Chanona, R. M., P. Mealy, A. Pichler, F. Lafond and J. D. Farmer, (2020), "Supply and demand shocks in the COVID-19 pandemic: An industry and occupation perspective", COVID Economics: Vetted and Real-Time Papers, Issue 6.

Demmou L., S. Calligaris, G. Franco, D. Dlugosch, M. Adalet McGowan and S. Sakha, (2021), "Insolvency and debt overhang following the COVID-19 outbreak: assessment of risks and policy responses", OECD Economics Department Working Papers No. 1651.

Demmou, L., I. Stefanescu and A. Arquié, (2019), "Productivity growth and finance: the role of intangible assets - a sector level analysis", OECD Economics Department Working Papers No. 1547.

European Central Bank, (2010), "Surveying the access to finance small and medium-sized enterprises in the Euro area: second half of 2009", Frankfurt: European Central Bank.

Gal, P., (2013), "Measuring total factor productivity at the firm level using OECD-ORBIS", OECD Economics Department Working Papers, No. 1049, OECD Publishing, Paris.

Kalemli-Ozcan, S., B. Sorensen, C. Villegas-Sanchez, V. Volosovych and S. Yesiltas (2015), "How to construct nationally representative firm level data from the ORBIS global database", NBER Working Paper, No. 21558.

OECD, (2020a), Economic Outlook December 2020, OECD Publishing, Paris.

OECD (2020b), "Global Financial Markets Policy Responses to COVID-19", OECD Tackling Coronavirus Series.

OECD, 2020c), "Job retention schemes during the COVID-19 lockdown and beyond", OECD Tackling Coronavirus Series.

OECD, (2020d), "Implications of the Covid-19 epidemic for firm ownership and bankruptcies", Forthcoming.

OECD (2020e), "Equity injections and unforeseen state ownership of enterprises during the COVID-19 crisis", OECD Tackling Coronavirus Series.

De Vito, A., and J.-P. Gomez, (2020), "Estimating the COVID-19 cash crunch: Global evidence and policy", Journal of Accounting and Public Policy, Vol .39(2).

Schivardi, F., and G. Romano, (2020), "A simple method to compute liquidity shortfalls during the COVID-19 crisis with an application to Italy", mimeo. 


\section{Annex A. Additional tables and figures}

Table A.1 Detailed dynamic of the three alternative revenues shock scenarios

\begin{tabular}{l|l|c|c|c|c|c|c|c|c|c|c}
\hline \multicolumn{2}{c}{$\begin{array}{c}\text { Months from the start of the } \\
\text { confinement }\end{array}$} & $\mathbf{1}$ & $\mathbf{2}$ & $\mathbf{3}$ & $\mathbf{4}$ & $\mathbf{5}$ & $\mathbf{6}$ & $\mathbf{7}$ & $\mathbf{8}$ & $\mathbf{9}$ & $\mathbf{1 0}$ \\
\hline $\begin{array}{l}\text { Size of } \\
\text { the shock }\end{array}$ & Upside scenario & $\mathrm{S}$ & $\mathrm{S}$ & $\mathrm{S}^{*} 0.75$ & $\mathrm{~S}^{\star} 0.4$ & $\mathrm{~S}^{*} 0.4$ & $\mathrm{~S}^{\star} 0.4$ & $\mathrm{~S}^{*} 0.2$ & $\mathrm{~S}^{*} 0.2$ & $\mathrm{~S}^{\star} 0.1$ & $\mathrm{~S}^{*} 0.1$ \\
\hline
\end{tabular}

Note: The tables shows the detailed dynamic underpinning each of the alternative scenarios. The revenues shock (S) is sector specific and calculated each month with respect to normal time revenues.

Table A.2 Number of firms by country

\begin{tabular}{l|r|r}
\hline Country & Total number of firms & \% of the sample \\
\hline BEL & 12,037 & 1.40 \\
\hline DEU & 2,801 & 0.33 \\
\hline DNK & 1,840 & 0.21 \\
\hline ESP & 202,731 & 23.59 \\
\hline FIN & 17,670 & 2.06 \\
\hline FRA & 52,614 & 6.12 \\
\hline GBR & 18,999 & 2.21 \\
\hline HUN & 82,821 & 9.64 \\
\hline IRL & 1,473 & 0.17 \\
\hline ITA & 288,091 & 33.53 \\
\hline POL & 22,526 & 2.62 \\
\hline PRT & 108,638 & 12.64 \\
\hline ROU & 5,499 & 0.64 \\
\hline SWE & 41,559 & 4.84 \\
\hline Total & 859,299 & 100 \\
\hline
\end{tabular}

Source: OECD calculations based on Orbis $®$ data. 
Table A.3. Firm-level descriptive statistics

\begin{tabular}{lrrrrrr}
\hline Variable & p5 & \multicolumn{1}{c}{ p25 } & p50 & \multicolumn{1}{c}{ mean } & p75 & p95 \\
\hline Number of employees & 3 & 5 & 8 & 38 & 19 & 106 \\
Gross revenues & 113,306 & 380,421 & 985,592 & $10,800,000$ & $3,149,000$ & $26,100,000$ \\
Value added & 39,191 & 128,364 & 307,468 & $2,293,000$ & 871,795 & $6,137,000$ \\
Intermediates & 46,000 & 203,669 & 597,060 & $8,481,000$ & $2,125,000$ & $19,400,000$ \\
Cash Flow & $(21,634)$ & 11,850 & 46,843 & 775,265 & 179,690 & $1,607,000$ \\
Ebitda & $(20,355)$ & 16,963 & 62,582 & 827,842 & 226,270 & $1,910,000$ \\
\hline Total Assets & 56,700 & 245,835 & 731,839 & $6,567,000$ & $2,539,000$ & $20,900,000$ \\
Fixed Assets & 2,117 & 29,407 & 134,781 & $4,927,000$ & 615,528 & $6,652,000$ \\
Cash Holdings & 1,368 & 15,269 & 62,429 & 515,844 & 243,048 & $1,900,000$ \\
Current Assets & 31,348 & 153,291 & 475,153 & $5,271,000$ & $1,643,000$ & $13,100,000$ \\
\hline Total Liabilities & 25,305 & 131,880 & 419,238 & $6,191,000$ & $1,479,000$ & $12,200,000$ \\
Current Liabilities & 16,398 & 90,118 & 291,689 & $4,056,000$ & $1,046,000$ & $8,870,000$ \\
Short-term financial debt & 0 & 0 & & 601,248 & 58,366 & $1,410,000$ \\
Non-Current Liabilities & 0 & 3,533 & 57,657 & $2,102,000$ & 285,000 & $2,582,000$ \\
\hline Long-Term financial debt & 0 & 0 & 8,830 & $1,461,000$ & 142,138 & $1,677,000$ \\
\hline Fixed Assets over Total Assets & 0.01 & 0.08 & 0.22 & 0.29 & 0.46 & 0.82 \\
Fixed Assets over Wage Bill & 0.02 & 0.17 & 0.59 & 3.76 & 1.73 & 8.24 \\
Cash Holdings over Total Assets & 0.00 & 0.03 & 0.10 & 0.18 & 0.26 & 0.60 \\
Cash Flow over Total Assets & -0.06 & 0.03 & 0.07 & 0.09 & 0.14 & 0.33 \\
\hline Total Liabilities over Total Assets & 0.14 & 0.41 & 0.65 & 0.68 & 0.85 & 1.03 \\
Financial Debt over Total Assets & 0.00 & 0.00 & 0.07 & 0.16 & 0.26 & 0.57 \\
Current Liabilities over Revenues & 0.06 & 0.16 & 0.27 & 0.45 & 0.46 & 1.11 \\
Interest Coverage Ratio & -8.17 & 4.60 & 15.70 & 2567 & 66.40 & 1312 \\
Net worth (total assets - total liabilities) & $(4,755)$ & 53,195 & 209,915 & $2,535,000$ & 876,364 & $8,361,000$ \\
\hline Fixed Assets minus Non-Current Liabilities & $(267,533)$ & 0 & 46,558 & $1,395,000$ & 308,069 & $4,137,000$ \\
\hline
\end{tabular}

Note: Monetary values are in EUR current (2018) prices.

Source: OECD calculations based on Orbis $₫$ data. 